\title{
The Tiger Lily.
}

Lilium superbum, Willd., Sp. Pl., vol. ii. p. 88. Pursh, Fl. Amer. Sept., vol. i. p. 280. -Hexandria Monogynia, Linn.-Liliacee, Juss.

This beautiful plant, which grows in swamps and moist copses, in the Northern and Eastern States, as far as Virginia, as well as in the western prairies, attains a height of four or five feet, and makes a splendid appearance with its numerous large drooping flowers, which sometimes amount to twenty or even thirty on a single stem. The leaves are linear-lanceolate, three-nerved, smooth, the lower verticillate, the upper scattered. The flowers are orange-yellow, spotted with black on their upper surface, the petals revolute.

\section{PHEASANT-TAILED GROUSE.-COCK OF THE PLAINS.}

†Tetrao urophasianus, Bonap.

Plate CCXCVII.-Male and Female.

Although the Cock of the Plains has long been known to exist within the limits of the United States, the rugged and desolate nature of the regions inhabited by it has hitherto limited our knowledge of its habits to the cursory observations made by the few intrepid travellers who, urged by their zeal in the cause of science, have ventured to explore the great ridge of mountains that separate our western prairies from the rich valleys bordering on the Pacific Ocean. Two of these travellers, my friends Mr. Townsend and Mr. Nuttald, have favoured me with the following particulars respecting this very remarkable species, the history of which, not being myself personally acquainted with it, I shall endeavour to complete by adding some notes of Mr. Douglas.

"Tetrao Urophasianus, Pi-imsh of the Wallah Wallah Indians, Makesh-too-yoo of the Nezpercee Indians, is first met with about fifty miles west of the Black Hills. We lose sight of it in pursuing the route by the Snake 


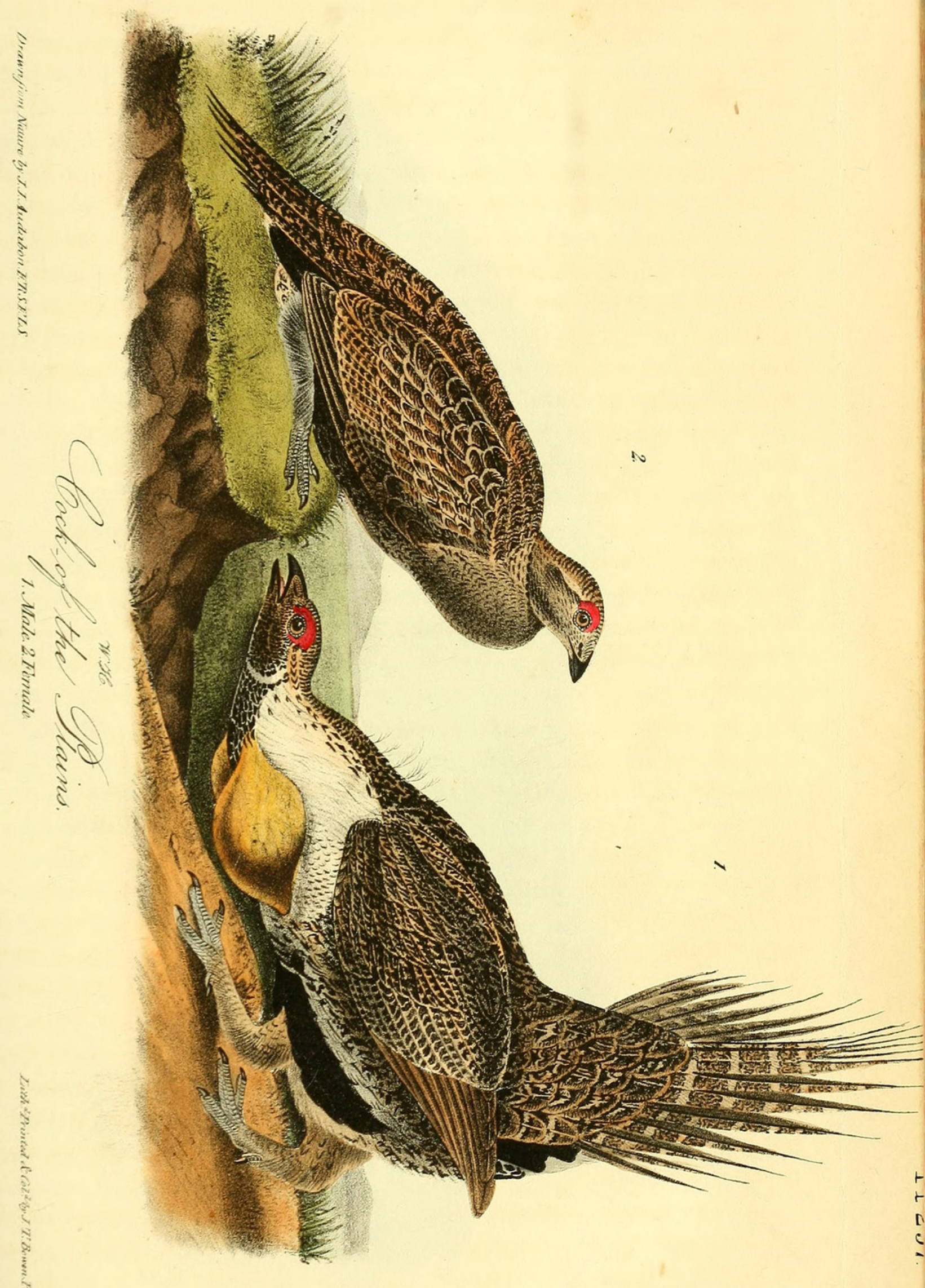



river until we reach Wallah Wallah, on the banks of the Columbia, near the mouth of Lewis river. This bird is only found on the plains which produce the worm-wood (Artemisia), on which plant it feeds, in consequence of which the flesh is so bitter that it is rejected as food. It is very unsuspicious, and easily approached, rarely flies unless hard pressed, runs before you at the distance of a few feet, clucking like the common hen, often runs under the horses of travellers when disturbed, rises very clumsily, but when once started, flies with rapidity to a great distance, and has the sailing motion of the Pinnated Grouse. In the autumn they frequent the branches of the Columbia river, where they feed on a narrow-leaved plant. At this time they are considered good food by the natives, who take great quantities of them in nets. J. K. Townsend."

"On the north branch of the Platte (Larimie's Fork) we begin to meet with the Tetrao Urophasianus in considerable numbers, always on the ground in small flocks or pairs, by no means shy, but when too nearly approached arising with a strong whirring noise, and uttering at the same time a rather loud but very short alarmed guttural cackle. The notes of the female indeed, at such times, almost resemble those of a common hen. The old male, when killed by Mr. Townsend, turned out so different from the imperfect and unadult specimens figured, that we could scarcely recognise it for the same species. Its size seemed to promise a fine meal, but appearances are often deceitful, and after being nicely broiled, it truly deserved to be treated like the well prepared plate of cucumbers, proving so very bitter, though delicately white, that our hungry hunters could scarcely swallow more than a morsel. In short, it feeds by choice on the bitterest shrubs of these sterile plains, and under-wood (several species of Artemisia) is literally its favourite food. Of its nest and breeding habits we ascertained nothing, but cannot for a moment hesitate to say that some mistake must exist in either asserting or supposing that a bird so constantly confined to the open desert plains, could retire to the shady forests and dark alluvial thickets of the Columbia to rear its young apart from their usual food and habits. We met with this very fine Grouse near to the plains around Wallah Wallah, on the south side of the Columbia, but never saw it either in the forests of the Columbia or the Wahlamet, nor, so far as we know, has it ever been found on the coast of California, or in the interior of Mexico. T. Nuttall."

Mr. Douglas's statement is as follows:- "The flight of these birds is slow, unsteady, and affords but little amusement to the sportsman. From the disproportionately small, convex, thin-quilled wing, - so thin that a vacant space half as broad as a quill appears between each,- the flight may be said to be a sort of fluttering, more than any thing else: the bird giving two or three claps of the wings in quick succession, at the same time hurriedly rising; 
then shooting or floating, swinging from side to side, gradually falling, and thus producing a clapping, whirring sound. When started, the voice is cuck, cuck, cuck, like the Common Pheasant. They pair in March and April. Small eminences on the banks of streams are the places usually selected for celebrating the weddings, the time generally about sunrise. The wings of the male are lowered, buzzing on the ground; the tail, spread like a fan, somewhat erect; the bare yellow œsophagus inflated to a prodigious size,fully half as large as his body, and, from its soft, membranous substance, being well contrasted with the scale-like feathers below it on the breast, and the flexile, silky feathers on the neck, which on these occasions stand erect. In this grotesque form he displays, in the presence of his intended mate, a variety of attitudes. His love-song is a confused, grating, but not offensively disagreeable tone,-something that we can imitate, but have a difficulty in expressing-Hurr-hurr-hurr-r-r-r-hoo, ending in a deep, hollow tone, not unlike the sound produced by blowing into a large reed. Nest on the ground, under the shade of Purshia and Artemisia, or near streams, among Phalaris arundinacea, carefully constructed of dry grass and slender twigs. Eggs, from thirteen to seventeen, about the size of those of a common fowl, of a wood-brown colour, with irregular chocolate blotches on the thick end. Period of incubation twenty-one to twenty-two days. The young leave the nest a few hours after they are hatched. In the summer and autumn months these birds are seen in small troops, and in winter and spring in flocks of several hundreds. Plentiful throughout the barren, arid plains of the river Columbia; also in the interior of North California. They do not exist on the banks of the river Missouri; nor have they been seen in any place east of the Rocky Mountains."

Tetrao urophasianus, Bonap. Amer. Orn., vol. iii. pl. 21.

Tetrao (Centrocercus) urophasianus, Cock of the Plains, Swains. \& Rich. F. Bor.

Amer., vol. ii. p. 358.

Cock of the Plains, Nutt. Man., vol. i. p. 666.

Cock of the Plains, Tetrao urophasianellus, Aud. Orn. Biog., vol. iv. p. 503.

Male, 30, 36. Female, 22.

Rocky Mountains and Columbia river, northward. Once seen on the Missouri. Abundant. Partially migratory from high to low grounds in autumn and winter.

Adult Male.

Bill shortish, strong, somewhat compressed; upper mandible with the dorsal line arcuato-declinate, the ridge flattened at the base and narrowed on account of the great extent of the nasal sinus, which is feathered, the sides convex toward the end, the edges inflected, the tip narrow and rounded; 
lower mandible with the angle of moderate length and width, the dorsal line ascending and convex, the edges sharp and inflected, the tip obtuse, but like the upper thin-edged. Head rather small, oblong; neck of moderate length; body full. Feet rather short, stout; tarsus roundish, feathered, bare and reticulated behind. Toes of moderate size, covered above with numerous scutella, laterally pectinated with slender projecting flattened scales; first toe small, second a little shorter than fourth, third much longer. Claws stout, slightly arched, moderately compressed, obtuse.

Plumage dense, soft, rather compact, the feathers in general broadly ovate; those on the head very short, on the sides of the neck anteriorly at its lower part and across the fore part of the breast, small, very short, broad, stiff, and imbricated like scales; higher up on the sides of the neck a tuft of feathers having their shafts elongated, bristle-like, and terminated by a few filaments. On each side of the lower part of the neck in front is a large bare space capable of being inflated into a hemispherical sac. On the fore part of the breast the feathers, although long, have the shaft thickened and elongated; the rest of the feathers are of ordinary structure. Wings rather short, concave, much rounded, the primaries stiff and very narrow, so as to leave a large interval when the wing is extended; the third, fourth, and fifth quills longest. Tail long, graduated, of twenty stiffish feathers, each tapering to a very elongated point.

Bill black; iris light hazel; superciliary membrane vermilion; toes brownish-grey; claws brownish-black. The upper parts are light yellowish-brown, variegated with brownish-black and yellowish-white; the feathers of the head and neck transversely barred, of the back barred, undulated and dotted, with a whitish longitudinal line along the shafts of the wing-feathers. The quills chocolate-brown, their outer webs and part of their inner margins mottled with yellowish-white. Tail with about ten bands of yellowishwhite on the outer webs, which are otherwise variegated like the back, the inner webs nearly plain brown. The throat and fore part of neck whitish, longitudinally spotted with brownish-black; a narrow white band across the throat; the sides of the neck and fore part of the breast white; the elongated shafts of the tuft-feathers black; the sides variegated like the back, with a broad line of white along the middle of each feather; the axillars and lower wing-coverts pure white; the hind part of the breast and the abdomen brownish-black; the sides of the rump like the back; the lower tail-coverts brownish-black, largely tipped with white; the feathers of the tibiæ and tarsi pale brownish-grey, faintly barred with brown.

Length to end of tail 30 inches; extent of wings 36; wing from flexure 13; tail 12 , shortest feathers 7 ; bill along the ridge $1 \frac{6}{12}$, along the edge of lower mandible $1 \frac{4}{12}$; tarsus $2 \frac{1}{2}$; hind toe $\frac{1}{2}$, its claw $\frac{4}{12}$; middle toe $2 \frac{1}{4}$, its claw $\frac{6}{12}$.

VoL. V. 
Adult Female.

The female is much smaller than the male, and differs in being destitute of the bare skin on the fore neck, in having the superciliary membranes smaller, the plumage entirely of ordinary texture; the tail less elongated, with the feathers less narrow and ending in a rounded point. All the upper parts, fore neck and sides are variegated with brownish-black, yellowishgrey and whitish, disposed nearly as in the male; the throat whitish, the fore part of the breast white, the middle part brownish-black, the legs and tarsi as in the male, as are the quills; the tail-feathers mottled like the back and tipped with white.

Length to end of tail 22 inches; wing from flexure $10 \frac{1}{2}$; tail $7 \frac{3}{4}$; bill along the ridge $1 \frac{4}{12}$; tarsus $1 \frac{10 \frac{1}{2}}{12}$; middle toe $1 \frac{8 \frac{1}{2}}{12}$, its claw $\frac{6}{12}$.

The size of this species has been exaggerated, it having been by some compared to the Turkey, and by others to the Great Wood Grouse of Europe, Tetrao Urogallus, whereas, in fact, it seems not much to exceed Tetrao hybridus. In some individuals, as I am informed by Mr. TownSEND, the hair-like shafts of the feathers on the sides of the neck are considerably longer than in my figure of the male.

\title{
S H A R P-T A I LED G R O US E.
}

\author{
+Tetrao Phasianellus, Linn.
}

Plate CCXCViII.-Male and Female.

This is another species of our birds with the habits of which I am entirely unacquainted. Dr. Richardson's account of it is as follows:- "The northern limit of the range of the Sharp-tailed Grouse is Great Slave Lake, in the sixty-first parallel; and its most southern recorded station is in latitude $41^{\circ}$, on the Missouri. It abounds on the outskirts of the Saskatchewan plains, and is found throughout the woody districts of the Fur Countries, haunting open glades or low thickets on the borders of lakes, particularly in the neighbourhood of the trading paths, where the forests have been partially cleared. In winter it perches generally on trees, in summer is much on the ground; in both seasons assembling in coveys of from ten to 


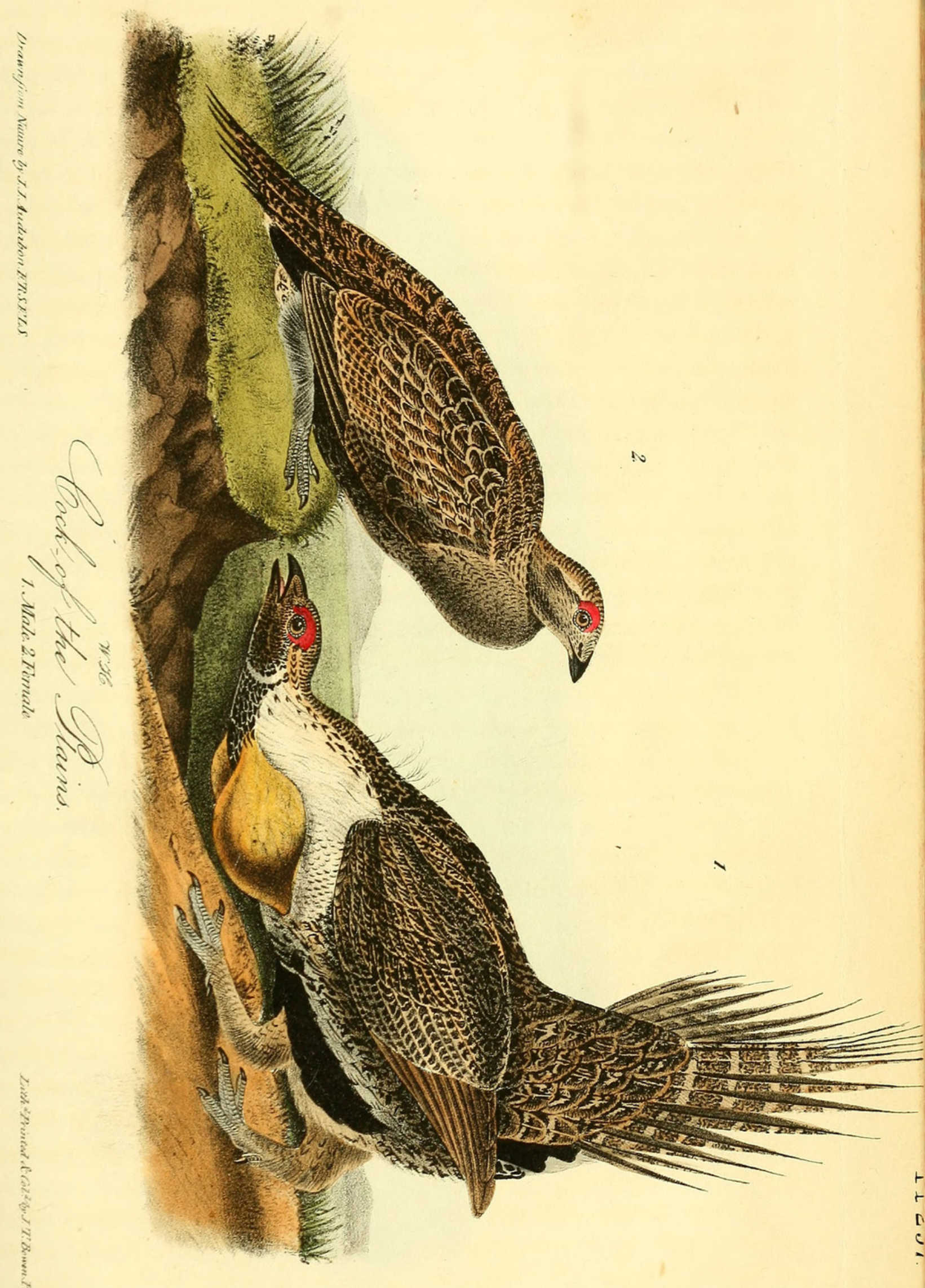




\section{$2 \mathrm{BHL}$ Biodiversity Heritage Library}

Audubon, John James. 1842. "Pheasant-Tailed Grouse-Cock of the Plains, Tetrao urophasianus, Bonap. [PI. 297]." The birds of America : from drawings made in the United States and their territories 5, 106-110.

https://doi.org/10.5962/p.319411.

View This Item Online: https://www.biodiversitylibrary.org/item/124982

DOI: https://doi.org/10.5962/p.319411

Permalink: https://www.biodiversitylibrary.org/partpdf/319411

\section{Holding Institution}

Smithsonian Libraries

\section{Sponsored by}

Biodiversity Heritage Library

\section{Copyright \& Reuse}

Copyright Status: NOT_IN_COPYRIGHT

This document was created from content at the Biodiversity Heritage Library, the world's largest open access digital library for biodiversity literature and archives. Visit BHL at https://www.biodiversitylibrary.org. 